Int. J. Morphol.,

32(2):537-541, 2014

\title{
Dental Pulp Fibroblast and Sex Determination in Controlled Burial Conditions
}

\author{
Fibroblastos de la Pulpa Dental y la Determinación del Sexo \\ en Condiciones Controladas de Enterramiento
}

\author{
Catherine Sandoval*; Marcelo Nuñez** \& Ignacio Roa*
}

\begin{abstract}
SANDOVAL, C.; NUÑEZ, M. \& ROA, I. Dental pulp fibroblast and sex determination in controlled burial conditions. Int. J. Morphol., 32(2):537-541, 2014.

SUMMARY: The need to identify bodies that are found as a result of disappearances with a diversity of causes, illegal burials and massive disasters, represent a wide percentage of dentistry practice on forensic research. The following study determined the performance of Barr Body Test, in fibroblasts of healthy teeth, under different conditions of burial (in vitro) with variations in $\mathrm{pH}$, humidity and salinity in terms of general accuracy and sensitivity for men and women. Analyzed sample considered 47 dental pulps, taken from teeth under burial conditions during a period of a month. From dental pulps samples, 265 histological cuts valid for this study, were obtained, which were observed with an optical microscope under conventional H/E staining. Results showed a 98.9\% of well-diagnosed cases, which correspond to the overall accuracy of the method. Sensitivity for men was $97.5 \%$ and $100 \%$ for women, over the analyzed sample. In low humidity conditions, 3 samples of badly diagnosed cases in men were observed, with a group accuracy of a $90 \%$, with a sensitivity of $25 \%$ for men and $100 \%$ for women. The present study establishes that based on these results, the performance of Barr Body Test in fibroblasts, proposed for healthy pulp teeth, is not affected by burial conditions in terms of $\mathrm{pH}$ (acid-alkaline), salinity (high-low) and high humidity.
\end{abstract}

KEY WORDS: Barr body; Fibroblast; Dental pulp; Sex identification; Burial conditions.

\section{INTRODUCTION}

The need to identify bodies that are found as a result of disappearances with a diversity of causes, illegal burials and massive disasters, represent a wide percentage of dentistry practice on forensic research (Pramod et al., 2012). But, in cases such as massive disasters, in which are only available indistinct tissue fragments, this work becomes more complex, as in cases in which mutilated or dismembered bodies are found, in order to hide the victim's identity (Saini et al., 2011).

One of the fundamental or key parameters to begin the process of forensic identification is sex estimation (Veeraraghavan et al., 2010), for which the use of genetic material is relevant (Iwamura et al., 2004). In the search of new, simple, quick and at lower cost methods, the observation of sexual chromatin or Barr Body has been used (Barr \& Bertram, 1949), which are found in several types of somatic cells (Vera et al., 1986), as is present in some cellular elements of dental pulp (Suazo et al., 2011).
Environmental conditions as; burial conditions and soil environment, where the observed tissues were found, have a critical role in the decomposition rate and erosion degree of hard tissues (Jaggers \& Rogers, 2009), which considerably affects forensic identification.

Based on of these findings, and in view of the lack of research that determines the burial conditions over the presence of Barr Body on dental pulp of healthy teeth, the purpose of this study is to determine and evaluate in vitro effects of burial conditions on the observation of this element on pulp fibroblasts, in the context of sex diagnostic.

\section{MATERIAL AND METHOD}

Sample. For the present study 56 teeth were used ( $\mathrm{n}=56,28$ women and 28 man) from different patients, aged between

\footnotetext{
* Department of Basic Biomedical Sciences, Faculty of Health Sciences, University of Talca, Talca, Chile.

${ }^{* *}$ Private Clinical Dentist, Chile.
} 
15 and 45 years (mean age for women of 23.9 years (SD 5.98) and for men of 20.7 (SD 3.35)), with no clinical history in syndromes of genetic etiology. Teeth used in this study were premolars and third molars extracted for orthodontic reasons.

Immediately after extraction, teeth were washed with water in order to remove residual blood and placed in an airtight container with physiological saline solution, labeled by age and sex, at room temperature and relative humidity of $100 \%$ until the proceedings are applied on the sample.

The sample, was divided into seven groups, according to the different burial conditions to which they were subjected, and each group had 4 teeth men and 4 women.

Selection Criteria. Were selected healthy third molars and premolars, with an extraction data which could not exceed three months, and with the respecting information of sex and age. Teeth with form or structure alterations, evidence of restorations or fractures in the post-surgical procedure, and teeth that belong to patients who express a syndromical genetic condition were excluded.

Method. After removing the 56 teeth form the airtight containers, 7 groups were formed of eight teeth each (4 women and 4 men), which were dried with absorbent paper and placed in plastic containers with $300 \mathrm{~g}$ of vermiculite for 4 weeks in a room at $20^{\circ} \mathrm{C}$ in the Technology Center of Soil and Crops, of the University of Talca, Chile. We registered the teeth's location, for further processing. In addition, all containers were labeled with their condition, reactive and total weight, which was restored by surface irrigation with bi-distilled water on alternate days, using an atomizer.

Group Distribution. The distribution of groups are shown in Table I. After 4 weeks, the teeth were removed from the boxes, and then we proceeded to make the camera access with a high-speed round bur of $0.12 \mathrm{~mm}$, under spray cooling, to access the pulp, which was extracted with a pulp extirpator. It was possible to extract the pulp of 47 teeth (21 men and 26 women).

Once removed, teeth pulps were fixed in $10 \%$ buffered formalin, for 24 hours. Of each pulp from the sample, 2 to 3 histological slides with 3 to 5 sections per board were obtained, depending on the amount of pulp removed from the teeth. After that, the conventional histological technique (H/E) was performed. Complete processing of the samples was performed at the Laboratory of Histology and Embryology, of the University of Talca, Chile.

Analysis Plan. The corresponding cuts were observed in a trinocular microscope, model CX21 (Olympus ${ }^{\circledR}$ ), with an 100X magnification. To consider positive the Barr Body test, it should be observed for plate, at least one fibroblast, presenting histological chromatin condensation at the nuclear periphery, according to the method previously described by Suazo et al. (2010). The observation was made with two observers, using double-blind analysis.

The results were expressed as: Men welldiagnosed $=$ Body Barr Test observation was negative observing teeth pulp obtained from man individuals as recorded. Men badly-diagnosed= Body Barr Test observation was positive observing teeth pulp obtained from man individuals as recorded. Women welldiagnosed $=$ Body Barr Test observation was positive observing teeth pulp obtained from woman individuals as recorded. Women badly-diagnosed $=$ Body Barr Test observation was negative observing teeth pulp obtained from woman individuals as recorded.

The statistical analysis. We calculated the overall accuracy of the method of the total sample on different burial conditions, as well as the sensitivity for men and women. Data were compared by the Fisher exact test and ChiSquare. For statistical analysis we used a $95 \%$ confidence level. To perform statistical analysis we used SPSS ${ }^{\circledR}$ Statistics 17 for Windows ${ }^{\circledR}$.

Table I. Distribution of groups.

\begin{tabular}{ccll}
\hline Group & $\mathbf{n}^{*}$ & \multicolumn{1}{c}{ Description } & \multicolumn{1}{c}{ Characteristics of soil } \\
\hline 1 & 8 & low salinity & $0.1667 \mathrm{~g} \mathrm{NaCl}$ diluted in $300 \mathrm{~mL}$ of bi-distilled $\mathrm{H}_{2} \mathrm{O}$ \\
2 & 8 & high salinity & $2.5 \mathrm{~g} \mathrm{NaCl}$ diluted in $300 \mathrm{~mL}$ of bi-distilled $\mathrm{H}_{2} \mathrm{O}$ \\
3 & 8 & acidic & $10.5 \mathrm{~mL}$ of $\mathrm{HCl} 0.1 \mathrm{~N}$, diluted in $300 \mathrm{ml}$ of bi-distilled $\mathrm{H}_{2} \mathrm{O}, \mathrm{pH} 4.5$ \\
4 & 8 & alkaline & $6 \mathrm{~mL}$ of NaOH $0.1 \mathrm{~N}$, diluted in $300 \mathrm{ml}$ of bi-distilled $\mathrm{H}_{2} \mathrm{O}, \mathrm{pH} 9.15$ \\
5 & 8 & high humidity & $222 \mathrm{~mL}$ of bi-distilled $\mathrm{H}_{2} \mathrm{O}$ \\
6 & 8 & low humidity & $74 \mathrm{~mL}$ of bi-distilled $\mathrm{H}_{2} \mathrm{O}$ \\
7 & 8 & Control & of pH (7.2), salinity of $0 \mathrm{dS} / \mathrm{m}$ and $300 \mathrm{ml}$ of bi-distilled $\mathrm{H}_{2} \mathrm{O}$ \\
$*=$
\end{tabular}




\section{RESULTS}

A total of 359 histological sections were obtained from the sample, of which 265 (147 women and 118 men) were validated for the study. In this study, the performance of the Barr Body Test in dental pulp was determined, in terms of presence or absence, using conventional $\mathrm{H} / \mathrm{E}$ staining of healthy teeth, under different burial conditions (in vitro) of $\mathrm{pH}$, humidity and salinity.

Identifying chromatin-positive cells showed a general accuracy of the diagnostic test for the overall samples subjected to burial conditions in a $98.9 \%$, and an overall sensitivity of $97.5 \%$ for men and $100 \%$ for women. In the control group were identified chromatin-positive cells, obtaining a group accuracy of $100 \%$ and sensitivity of $100 \%$ for men and women (Fig. 1).

In the condition of acid and alkaline $\mathrm{pH}$, it was possible to identify chromatin-positive cells, obtaining an accuracy of $100 \%$ in the group, and $100 \%$ sensitivity for both men and women. In high humidity conditions, it was possible to identify chromatin-positive cells, obtaining an accuracy of $100 \%$ in the group, and sensitivity of $100 \%$ for men and women. With regard to the low humidity condition there was a statistically significant decrease for accuracy and sensitivity in group for men, with values of $90 \%$ and $25 \%$, respectively. Finally, in the condition of low and high salinity, it was possible to identify chromatin-positive cells, achieving an accuracy of $100 \%$ in the group, and sensitivity of $100 \%$ for males and females.

\section{DISCUSSION}

The forensic identification process can be solved relatively easily if the bodies to be identified present little tissue damage have some documentation, or previous records. However, when war conflicts, terrorist acts or mass disasters occur, where bodies to be identified present a high degree of tissue destruction, the recognition process becomes very difficult, so there is a need to use different techniques to clarify the identity of the individual.

The estimation of sex is one of the pillars of forensic identification (Ross \& Manneschi, 2011), of great importance in the analysis in cases of natural disasters, illegal burials or dental findings of another nature, where sex recognition is not possible through other methods (Pillay, 2001).

The use of the tooth pulp tissue is useful in these cases, because of the protection given by hard dental tissues against environmental conditions, that maintains cell viability (Hemanth et al., 2008). The pulp tissue is shown as a good choice for collecting organic material, with the exception that its amount varies depending on various conditions such as age, where most adult pulp has a higher amount of fibres and few cellular elements (Pashley \& Walton, 1994). Pathological processes such as cavities, alter the tissue composition of the pulp (Morales et al., 2014), whereby the use of young teeth without pathologies was necessary for this study.

As a result of the decomposition of a body under

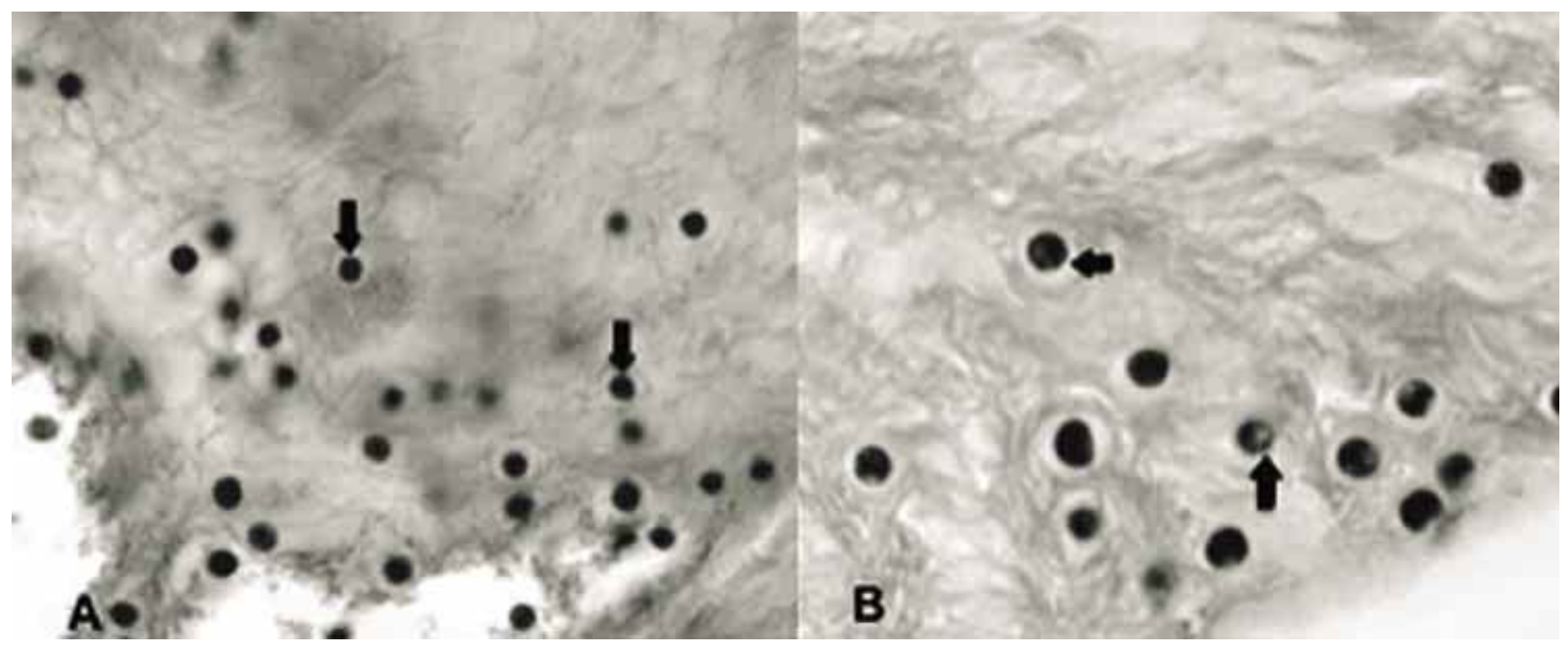

Fig. 1. A. Histologic section of male dental pulp. Negative cells were observed for the observation of Barr bodies (Arrows indicate the nucleus); H/E, 100X. B. Histologic section of female dental pulp. Positive cells were observed for the observation of Barr bodies (Arrows indicate the condensation of sexual chromatin); H/E, 100X. 
burial conditions, teeth are often the only feature that remains identifiable from a skeleton. As decomposition progresses, loss of soft tissue around the jaws allows the teeth to be exposed and evicted from their original anatomical position. Post mortem tooth loss has been described as a possible indicator of post mortem interval, and seems to depend on the age, periodontal health, climate and location of the body (Tibbert $\&$ Carter, 2008).

A simple test to determine the sex of an individual is the Barr Body observation, which is present in the nuclear membrane of female cells and also present in various tissues as well as in healthy tooth pulp cells (Suazo et al., 2010).

This method is quick and easy to implement, requires little equipment in contrast to other techniques such as PCR (Murakami et al., 2000). On the other hand Barr bodies can be observed with a number of nuclear stains such as hematoxylin-eosin, Papanicolaou, Feulgen, cresyl violet, aceto-orcein, carbol fuchsin (Duffy et al., 1991). So this method is shown as a valid and economical option when compared with DNA analysis techniques.

The obtained result (under wet conditions), was similar to those reported by Das et al. (2004) who reported a sensitivity to the technique of $100 \%$ for women, under observation in staining Barr body $\mathrm{H} / \mathrm{E}$ to smearing of pulp cells of canines and incisors extracted from jaws of a body deposit, under uncontrolled conditions of humidity.

Humidity conditions were controlled and varied from $30 \%$ to $100 \%$, in contrast to the study by Das et al., who reported that it was more reasonable to find the Barr body in ranges from $68.8 \%$ to $79.9 \%$ of humidity. It is important to point out that the difference may be rooted in soil substrate differences, as our study was conducted in an inert substrate.

Tibbet \& Carter argue that soils that have a highly acidic $\mathrm{pH}$, descomposed rapidly the hard tissues, due to the dissolution of the inorganic matrix in the hydroxyapatite. These findings were not considered of extreme importance to this study, since the sensitivity of the diagnostic test to samples exposed to acid and alkaline $\mathrm{pH}$ was $100 \%$ in men and women.

As for the salinity variable and according to previously considered literature, there is no evidence that sex has been estimated by the Barr Body under burial conditions, so, our results are useful for future studies.

In the present study, the overall accuracy decreased to 98.9\% and sensitivity to $97.5 \%$ in males compared to the gold standard on healthy pulps obtained by Suazo et al. (2010). This study is unprecedented in the association of variables to which samples were exposed, but results can be analyzed separately to look for similarities with other studies. Even when generated burial conditions are not comparable to a real soil, similar results can be expected in real soils with these conditions. The study presented (in vitro), conditions similar to those of decaying bodies buried underground, because it eliminates the environmental variables from decomposed bodies present on the surface, as scavengers, insects and physical variables such as external trauma and materials associated with bodies such as clothing. Moreover, vermiculite soil by not being real soil but a mineral substrate, does not present microorganisms that accelerate the natural decomposition of tissues in the ground, and that is why the same conditions of $\mathrm{pH}$, salinity and in vitro humidity were generated, considering the temperature variable as constant, which sets it apart with forensic taphonomy studies, as they deliver data from actual burial cases, studying only the conditions presented by the ghastly discovery. However, in this research contrasting conditions to evaluate the diagnostic test were generated instead.

Therefore, we present relevant information about the diagnostic value of the observation of the Barr body in teeth subjected to different burial conditions (in vitro) as moisture, salinity and $\mathrm{pH}$. It is suggested to evaluate the performance of this test in real soil, with the presence of environmental factors, in order to observe the performance of the diagnostic test in temperature and humidity conditions favorable for bacterial metabolism.

This study can establish that the diagnostic test performance observation for the Barr body, proposed for pulp of healthy teeth, was not affected by the proposed burial conditions in terms of $\mathrm{pH}$ (acid-alkaline), salinity (high-low), and humidity (high). In low humidity conditions, this cannot be stated, since the sensitivity for men decreased to $25 \%$, and bodies found in dry conditions may not show reliable results.

As seen above, it can be indicated that if a human tooth discovery is produced, from any source under described conditions, we can use this diagnostic test to estimate the sex of the individual, with a $98.9 \%$ of certainty, in similar settings of burial to those described in this study.

SANDOVAL, C.; NUÑEZ, M. \& ROA, I. Fibroblastos de la pulpa dental y la determinación del sexo en condiciones controladas de enterramiento. Int. J. Morphol., 32(2):537-541, 2014.

RESUMEN: La necesidad de identificar cuerpos que resultan como consecuencia de desapariciones de causas variadas, inhumaciones ilegales y desastres masivos representa un porcentaje amplio en el quehacer odontológico en un escenario de investigación forense. El presente estudio determinó el rendi- 
miento de la prueba diagnóstica de observación del cuerpo de Barr en células de la pulpa de dientes sanos, sometidos a distintas condiciones de enterramiento (in vitro) con variación de $\mathrm{pH}$, humedad y salinidad en términos de exactitud general y sensibilidad para hombres y mujeres. La muestra analizada consideró 47 pulpas dentales, extraídas de dientes sometidos a condiciones de enterramiento durante un mes. De las pulpas dentarias se obtuvieron 265 cortes histológicos válidos para el estudio, los cuales mediante la tinción convencional $\mathrm{H} / \mathrm{E}$, fueron observados al microscopio óptico. Los resultados arrojaron un 98,9\% de casos bien diagnosticados, que correspondió a la exactitud general del método. La sensibilidad para hombres fue de $97,5 \%$ y para mujeres de $100 \%$ sobre el total de la muestra analizada. Las condiciones de $\mathrm{pH}$ (ácido y alcalino), salinidad (alta y baja) y alta humedad presentaron una exactitud de grupo de $100 \%$, con una sensibilidad para hombres y mujeres de $100 \%$. En la condición de baja humedad se observaron 3 muestras de hombres mal diagnosticadas con una exactitud de grupo de $90 \%$ y sensibilidad para hombres de $25 \%$ y para mujeres de $100 \%$. A la luz de los resultados, el presente estudio establece que el rendimiento de la prueba diagnóstica de observación del cuerpo de Barr en fibroblastos, propuesto para pulpas de dientes sanos, no se afecta con las condiciones de enterramiento propuestas bajo $\mathrm{pH}$ ácido - alcalino, salinidad alta - baja y humedad alta.

PALABRAS CLAVE: Cromatina de Barr; Fibroblastos; Pulpa dental; Identificación de sexo; Condiciones de enterramiento.

\section{REFERENCES}

Barr, M. \& Bertram, E. A morphological distinction between neurons of the male and female, and the behaviour of the nucleolar satellite during accelerated nucleoprotein synthesis. Nature, 163(4148):676-7, 1949.

Das, N.; Gorea, R. K.; Gargi, J. \& Singh, J. R. Sex determination from pulpal tissue. JIAFM, 26(2):50-4, 2004.

Duffy, J. B.; Waterfield, D. J. \& Skinner, M. C. Isolation of tooth pulp cells for sex chromatin remains. Forensic Sci. Int., 49(2):127- 41, 1991.

Hemanth, M.; Vidya, M.; Nandaprasad \& Bhavana. Sex determination using dental tissue. Med. Leg. Update, 8(2):7-12, 2008.

Iwamura, M.; Soares, D. \& Romero, M. Human identification and analysis of DNA in bones. Rev. Hosp. Clin. Fac. Med. S. Paulo, 59(6):383-8, 2004.

Jaggers, K. A. \& Rogers, T. L. The Effects of Soil Environment on Postmortem Interval: A Macroscopic Analysis. J. Forensic. Sci., 54(6):1217-22, 2009.

Morales, R.; Trujillo, E. \& Cantín, M. Stereological Characterization of Odontoblasts in Normal Healthy and Reversible Pulpitis in Human Dental Pulps. Int. J. Morphol., 32(1):154-60, 2014.
Murakami, H.; Yamamoto, Y.; Yoshitome, K.; Ono, T.; Okamoto, O.; Shigeta, Y.; Doi, Y.; Miyaishi, S. \& Ishizu, H. Forensic study of sex determination using PCR on teeth samples. Acta Med. Okayama, 54(1):21-32, 2000.

Pashley, D. \& Walton, R. Histology and physiology of the dental pulp. In: Ingle, J. \& Bakland, L. (Ed.) Endodontics. 4th ed. Malvern: Williams \& Wilkins, 1994.

Pillay, V. V. MKR Krishnan's Handbook of Forensic Medicine and Toxicology. 12th ed. Hyderabad: Paras Publication, 2001.

Pramod, J. B.; Marya, A. \& Sharma, V. Role of forensic odontologist in post mortem person identification. Dent. Res. J., 9(5):522-30, 2012.

Ross, A. H. \& Manneschi, M. J. New identification criteria for the Chilean population: Estimation of sex and stature. Forensic Sci. Int., 204(1-3):206.e1-206.e3, 2011.

Saini, V.; Srivastava, R.; Rai, R.; Shamal, S.; Singh, T. \& Tripathi, S. Mandibular Ramus: An Indicator for Sex in Fragmentary Mandible. J. Forensic. Sci., 56(1):13-6, 2011.

Suazo, G. I. C.; Flores, A.; Roa, I.; Cantín, M. \& Zavando, D. Sex determination by observation of Barr body in teeth subjected to high temperatures. Int. J. Morphol., 29(1):199-203, 2011.

Suazo, G. I.; Roa, H. I. \& Cantín, L. M. Sex chromatin in dental pulp. Performance of diagnosis test and gold standard generation. Int. J. Morphol., 28(4):1093-6, 2010.

Tibbet, M. \& Carter, D. Cadaver decomposition and soil: Processes. In: Soil analysis in forensic taphonomy. Chemical and biological effects of buried human remains. Boca Raton, CRC Press, Taylot \& Francis Group, 2008.

Veeraraghavan, G.; Lingappa, A.; Shankara, S. P.; Mamatha, G. P.; Sebastian, B. T. \& Mujib, A. Determination of from tooth pulp tissue. Libyan J. Med., 5:5084, 2010.

Vera, D.; Youlton, R. \& Cecilia, B. Cromatina de Barr: Análisis de su valor actual. Rev. Chil. Pediatr., 57(6):506-9, 1986.

Correspondence to:

Dr. Ignacio Roa H.

Department of Basic Biomedical Sciences

Faculty of Health Sciences

University of Talca, Av. Lircay s/n, Talca

CHILE

Email: iroa@utalca.cl

Received: 26-11-2013

Accepted: 22-03-2014 